\title{
Menggagas Ruang Publik Berbasis Demokrasi Deliberatif: Studi Dinamika Pengelolaan Ruang Publik Terpadu Ramah Anak (RPTRA) di Jakarta Utara
}

\section{Initiating Deliberative Democracy-Based Public Space: A Study on Dynamic Management of Child-Friendly Integrated Public Space (RPTRA) in North Jakarta}

\author{
Dodi Faedlulloh, Retnayu Prasetyanti, Indrawati \\ Prodi Ilmu Administrasi Publik \\ Universitas 17 Agustus 1945 Jakarta \\ dodifaedlulloh@gmail.com
}

\begin{abstract}
Abstrak
Pemerintah Provinsi DKI Jakarta sedang melakukan upaya membangun kanal-kanal ruang publik untuk merubah wajah kota dengan cara membangun Ruang Publik Terpadu Ramah Anak (RPTRA) sebagai upaya mendukung Jakarta menjadi Kota Layak Anak. Berbeda dengan gagasan Jürgen Habermas yang menjelaskan konsep ruang publik sebagai ruang yang mandiri dan terpisah dari negara dan pasar, RPTRA justru merupakan hasil dari kemitraan antara pemerintah dengan perusahaan melalui CSR. Penelitian ini ditujukan untuk menganalisa RPTRA dalam perspektif ruang publik yang berbasis demokrasi deliberatif. Adapun lokasi penelitian ini yaitu RPTRA Sungai Bambu dan RPTRA Sunter Jaya Berseri yang keduanya berada di Kota Administrasi Jakarta Utara. Proyek pembangunan RPTRA merupakan momentum untuk mengoptimalkan dan memperluas ruang-ruang publik yang mampu diakses dan dikontrol lansung oleh publik di DKI Jakarta pada umumnya, dan Jakarta Utara khususnya. Metode penelitian yang digunakan dalam penelitian ini yaitu penelitian kualitatif dengan menggali informasi dan data melalui observasi langsung, wawancara mendalam, dan dokumentasi. Hasil dari penelitian ini menunjukan bahwa RPTRA telah memenuhi karakter ruang publik sebagai ruang interaksi masyarakat, dikelola dan dikontrol bersama untuk kepentingan publik, terbuka bagi semua tanpa kecuali, dan secara relatif menjadi ruang kebebasan dan aktualisasi bagi warga. Namun bila ditinjau dalam perspektif demokrasi deliberatif, kekurangan terjadi saat proses pembangunan RPTRA karena warga tidak dilibatkan secara aktif. Aktor yang dominan dalam proses pembangunan adalah pihak swasta dan pemerintah. Adapun transformasi demokrasi deliberatif tercipta saat pada proses pengelolaan RPTRA.
\end{abstract}

\section{Kata Kunci: Ruang Publik, RPTRA, CSR}

\begin{abstract}
The government of DKI Jakarta province is attempting to build public space channels to change the city face by means of constructing Children-Friendly Public Space (thereafter called RPTRA) as the attempt of supporting Jakarta to be Children-Friendly City. In contrast to Jurgen Hubermas' idea explaining public space concept as an independent space separated from the state and the market, RPTRA is instead the product of partnership between government and companies through CSR. This research aimed to analyze RPTRA in public space perspective based on deliberative democracy. This research was taken place in RPTRA
\end{abstract}


Sungai Bambu and RPTRA Sunter Jaya Berseri, both of which are located in North Jakarta Administrative City. The RPTRA development project is a moment to optimize and to expand the public spaces accessible and controllable to the public in DKI Jakarta in general and North Jakarta in particular. The research method employed was qualitative one by means of exploring information and data through direct observation, in-depth interview, and documentation. The result of research showed that RPTRA had fulfilled the character of public space as society interaction room, managed and controlled jointly for the sake of public interest, opened to everyone, and relatively becoming the space of freedom and actualization to the citizens. However, viewed from deliberative democracy perspective, the limitation occurred during RPTRA construction process because the citizens did not participate actively. The dominant actors in construction process were private and government. Deliberative democracy transformation was created during RPTRA management process.

\section{Keywords: Public Space, RPTRA, CSR}

\section{A. Pendahuluan}

Jakarta menjadi salah satu kota yang paling padat di dunia. Sebagai kota yang menjadi pusat pemerintahan dan juga pusat ekonomi membuat Jakarta seperti magnet yang terus dikunjungi oleh masyarakat Indonesia dari segala penjuru. Setiap tahun jumlah penduduk semakin bertambah. Data terakhir tahun 2014 dari BPS menginformasikan penduduk di DKI Jakarta berjumlah lebih dari sepuluh juta jiwa. Implikasi dari masalah kependudukan ini mengakibatkan berbagai masalah sosial turunan lainnya. Banyak permasalahan keseharian yang dihadapi oleh kaum urban Jakarta. Permasalahan kepadatan penduduk mempersempit ruang gerak masyarakat yang tinggal di sekitar Jakarta. Ruang berinteraksi pun menjadi minim karena lahan-lahan telah banyak digunakan untuk membangun gedung-gedung tinggi dan perumahan. Padahal masyarakat membutuhkan ruang yang dimanfaatkan untuk berkumpul, berekspresi dan beraspirasi. Dalam konteks ini, saat ini Pemerintah Provinsi DKI sedang melakukan upaya membangun kanalkanal ruang publik tersebut untuk merubah wajah kota.

Komisi Nasional Perlindungan Anak (Komnas PA) menyatakan Jakarta merupakan kota yang paling tinggi tingkat kekerasan terhadap anak (www.tempo.com 2015). Banyak faktor yang menyebabkan permasalahan ini saling berkelindan, mulai karena faktor ekonomi, sosial, dan hukum. Oleh karena itu dalam rangka mewujudkan komitmen guna menjamin terpenuhinya hak anak untuk hidup, tumbuh, berkembang dan berpartisipasi secara optimal sesuai dengan harkat dan martabat kemanusiaan serta mendapat perlindungan terhadap kekerasan dan diskriminasi, Pemerintah Provinsi DKI Jakarta telah membangun beberapa Ruang Publik Terpadu Ramah 
Anak (RPTRA) sebagai upaya mendukung Jakarta menjadi Kota Layak Anak.. Targetnya yaitu Jakarta akan memiliki 306 taman di tahun 2017 (www.news.detik.com, 2016). Sampai bulan Maret 2017 setidaknya sudah ada 185 RPTRA yang tersebar dan sudah diresmikan oleh Pemprov DKI Jakarta. Inisiasi Pemerintah DKI Jakarta ini merupakan agenda yang menarik dan segar di tengah permasalahanpermasalahan kepadatan penduduk dan mempersempitnya ruang gerak bagi masyarakat ibu kota.

Selain pembangunan fisik, RPTRA secara tidak langsung juga membangun harapan karena memiliki potensi berperan menjadi melting pot warga dengan berbagai latar belakang yang heterogen dan menjadi katalisator ragam kegiatan masyarakat, dari mulai aktivitas sosial, budaya bahkan rekreasi keluarga. Ruang publik mengakomodasi interaksi sosial. Bila hal ini berlangsung secara berkelanjutan dapat mendorong pembelajaran bagi masyarakat untuk saling mengerti satu sama lain, ruang berbagi antara komunitas yang berbeda, hingga akhirnya membangun kesatuan pemahaman tentang kebhinekaan sebagai sesuatu yang niscaya.

Konsep berbeda yang ditawarkan dalam RPTPA yaitu lahan yang dibangun tidak sekedar menjadi taman semata. RPTPA didorong untuk dapat memenuhi 31 Indikator kota layak anak yang ditetapkan Kementarian Pemberdayaan Perempuan dan Anak (Kemen PPA). Hal menarik lainnya yaitu RPTRA dibangun dekat dengan permukiman warga, terutama warga miskin. Sehingga RPTRA dapat berperan sebagai community center bagi masyarakat sekitar (www.news.detik.com 2016).

Sebagai community center, RPTPA dicitacitakan memiliki multifungsi yang bisa mengakomodasi aktivitas dan suara masyarakat, dari mulai aktivitas seperti olahraga, kegiatan kesehatan ibu dan anak, bahkan sebagai prasarana pendidikan politik. Selain itu, disediakan pula perpustakaan, tempat bermain futsal, jogging track, hingga amphi theater. Fasilitas tersebut untuk menopang kegiatan-kegiatan anak maupun remaja secara positif (www.fastnews.com 2015). Adapun fungsi RPTRA sesuai dengan Peraturan Gubernur Provinsi Daerah Khusus Ibukota Jakarta Nomor 196 Tahun 2015, pasal 6 sebagai berikut:

1. Taman terbuka publik

2. Wahana permainan dan tumbuh kembang anak

3. Prasarana dan sarana kemitraan antara Pemerintah Daerah dan masyarakat dalam memenuhi hak anak

4. Bagian dari prasarana dan sarana Kota Layak Anak

5. Ruang terbuka hijau dan tempat penyerapan air tanah

6. Prasarana dam sarana kegiatan sosial warga, termasuk pengembangan pengetahuan dan keterampilan kader PKK 
7. Usaha peningkatan pendapatan keluarga

8. Pusat informasi dan konsultasi keluarga

9. Halaman keluarga yang asri teratur indah dan nyaman, dan

10. Sistem informasi manajemen

Banyak fungsi yang diharapkan bisa dimanfaatkan oleh khalayak luas dari proses pembangunan RPTPA ini, bahkan tidak hanya yang bersifat publik, untuk ihwal yang bersifat privat (seperti tempat pernikahan bagi yang tidak mampu) pun bisa difasilitasi. Tentunya dalam hal ini pemerintah pun berharap besar pihak yang mendapatkan keuntungan dan manfaat terbesar dari keberadaan taman tiada lain adalah warga di sekitar RPTRA.

Proses pembangunan RPTRA melibatkan masyarakat sekitar. Bahkan perawatan taman juga dilakukan oleh masyarakat di sekitar RPTRA dan dikoordinir oleh ibuibu PKK. Sederhananya, RPTRA memosisikan warga sebagai pemilik dan pengelola taman, bukan sekadar penikmat taman. Berarti ada proyeksi RPTRA ini benar-benar menjadi ruang publik yang memberikan akses kepada setiap warga negara untuk menjadi subjek yang mandiri dan rasional serta memastikan setiap orang menjadi pengusung opini publik di ruang yang dibangun bersama tersebut.

Berbeda dengan gagasan Jürgen Habermas yang menjelaskan konsep ruang publik sebagai ruang yang mandiri dan terpisah dari negara (state) dan pasar (market), justru dalam RPTRA ini berada di antaranya, karena RPTRA dibangun dan dirawat tanpa menggunakan dana APBD. Adapun dana pembangunan RPTRA berasal dari sumbangan CSR sejumlah perusahaan. Sebanyak 11 perusahaan swasta memberikan sumbangan CSR untuk membantu membangun RPTRA di antaranya seperti Agung Sedayu Group, Summarecon Agung, Agung Podomoro, Ciputra, Intiland Development, PT Djarum (Blibli.com), Metropolitan Kencana, Barito Pacific, Alfa Goldland (Alam Sutra), Nestle Indonesia, Dharma Suci. Sementara perguruan tingginya yaitu Universitas Indonesia, Universitas Hamka, Unversitas Mercu Buana, Universitas Ibnu Chaldun, dan Univeritas Bunda Mulia (www.jakarta.bisnis.com 2015). Akan tetapi hal inilah yang menjadi menarik. Bukan lantas ide Habermas menjadi tidak kontekstual, justru gagasan Habermas bisa menjadi pijakan awal dalam melihat kepublikan dari ruang publik yang difasilitasi kemitraan antara negara dan pasar.

Di antara RPTRA-RPTRA yang sudah diresmikan di berbagai wilayah di DKI Jakarta, Jakarta Utara menjadi salah satu kota yang dijadikan proyek pembangunan RPTRA di tahun 2015. Di Jakarta Utara sendiri di antaranya RPTRA Sungai Bambu yang diresmikan pada tanggal 13 Mei 2015 dan RPTRA Sunter Jaya Berseri diresmikan tanggal 18 Desember 2015 lalu. RPTRA yang telah dibangun akan 
ada pengurusnya, sehingga pelibatan aktif dari masyarakat sekitar menjadi perlu untuk menjaga dan mengawal keberadaan RPTRA. Selain itu, RPTRA juga bisa berperan pemberdayaan masyarakat. Seperti yang dilansir beberapa media, Gubernur DKI Jakarta Basuki Purnama mengharapkan ketika ada persoalanpersolan masyarakat sekitar bisa langsung terserap informasinya dengan cepat, sehingga bisa langsung dilakukan antisipasi dan memberikan solusi (www.jakarta.bisnis.com 2015).

Penelitian ini berlokasi di Jakarta Utara, dengan studi di RPTRA Sungai Bambu dan RPTRA Sunter Jaya Berseri. Jakarta Utara memiliki sisi yang menarik untuk dikaji lebih dalam karena $24,1 \%$ dari 12.500.000 penduduk DKI tersebar di Kota Administrasi Jakarta Utara. Hal ini menandakan penduduk di Jakarta Utara sangat padat. Konsekuensi permasalahan kepadatan penduduk ini yaitu ruang gerak masyarakat yang menjadi sempit. Luas daratan Kota Administrasi Jakarta Utara adalah $139,560 \quad \mathrm{KM}^{2}$, sedangkan rekapitulasi luas taman dari data yang dilansir dari Sudin Pertamanan Kota Administrasi Jakarta Utara (2014) seluas 320,391,14 $\mathrm{M}^{2}$. Hal ini kembali menunjukan secara keruangan di Jakarta Utara masih belum optimal. Oleh karenanya pendirian RPTRA adalah momentum bagi Jakarta Utara untuk memperluas ruang terbuka untuk publik, tentunya dengan lebih banyak memberikan peran aktif langsung dari masyarakat yang lebih emansipatif.

\section{B. Metode Penelitian}

Secara sistematis, penelitian ini menggunakan metode kualitatif. Metode kualitatif merupakan prosedur pengumpulan data yang menghasilkan data deskriptif berupa kata-kata tertulis atau lisan dari orang-orang dan perilaku yang diamati (Moleong 2004). Sedangkan untuk memilih informan peneliti menggunakan purposive sampling. Lokasi penelitian dilakukan di RPTRA Sungai Bambu dan RPTRA Sunter Jaya Berseri. Untuk mengukur validitas penelitian, peneliti menggunakan triangulasi sumber dengan membandingkan data hasil pengamatan dan wawancara, keadaan dengan perspektif orang, dan hasil wawancara dengan isi dokumen (Moleong 2004).

\section{Hasil dan Pembahasan \\ a. Membaca Ruang Publik}

Dalam Ruang publik semua warga negara memiliki akses dalam menyuarakan dan merundingkan aspirasinya untuk mendorong menjadi opini publik. Opini publik ini berperan untuk mempengaruhi segala yang ada dalam ruang publik, baik secara formal maupun informal, untuk melakukan produksi dan sirkulasi diskursus yang secara prinsip merupakan hal yang sangat penting bagi negara. Ruang publik juga bukan seperti pasar tempat bertemunya penjual dan pembeli, tetapi merupakan tempat untuk hubunganhubungan yang berbeda-beda dan menjadi tempat untuk melakukan perdebatan dan permusyawaratan. Singkatnya, ruang publik berarti sebuah ruang yang menjadi 
mediasi antara masyarakat dan negara di mana publik mengatur dan mengorganisirnya sendiri sebagai pemilik opini publik. Konsep ruang publik diambil dari sejarah ruang publik kaum borjuis di Jerman pada abad delapan belas (Habermas 1964). Habermas memberi tafsiran ruang publik borjuis saat itu berfungsi untuk memediasi keprihatinan individu-individu dalam kehidupan sosial, ekonomi, dan keluarga, yang dihadapkan dengan tuntutan-tuntutan dan keprihatinan dari kehidupan sosial dan publik. Walaupun kemudian Habermas menjelaskan tentang kematian ruang publik karena transisi dari kapitalisme liberal ke kapitalisme monopoli (Eley 1992), dia tetap berargumen bahwa ruang publik tetap bisa dijadikan sebuah tipe ideal (Habermas 1992) untuk prospek demokrasi pada masa kini.

Ruang publik ideal akan terbentuk ketika topik diskusi yang terbangun dibatasi pada kebaikan bersama. Dalam proses tersebut, para partisipan ditransformasikan dari koleksi pencarian diri sendiri, individu pribadi ke dalam semangat publik secara kolektif, mampu untuk bertindak bersama dalam kepentingan bersama. Dalam pandangan ini, kepentingan individu tidak punya tempat yang layak dalam politik ruang publik (Kadarsih 2008).

RPTRA merupakan bagian dari bagian dari perspektif perancangan kota. Sebagai ruang publik, maka RPTRA akan menjadi fokus utama dalam proses dan produk dalam persfektif perancangan kota. Sunaryo et al., (2010) menjelaskan karakter-karakter ruang publik sendiri yaitu: Pertama, ruang publik merupakan tempat masyarakat berinteraksi, melakukan beragam kegiatan secara berbagi dan bersama, meliputi interaksi sosial, ekonomi dan budaya, dengan penekanan utama pada aktivitas sosial. Kedua, ruang publik diadakan, dikelola dan dikontrol secara bersama, baik oleh negara atau privat, yang didedikasikan untuk kepentingan publik. Hal ini menjadi relevan dengan kajian dalam penelitian ini, mengingat RPTRA yang dibangun merupakan hasil dari kerjasama antara negara dan pasar melalui CSR. Ruang publik tentunya tidak berjalan di ruang hampa, akan ada perubahan-perubahan yang terjadi yang akan mempengaruhi status kepemilikan ruang publik. Namun dalam konteks perubahan ini masih dapat ditarik ikhtisar bahwa ruang yang didedikasikan untuk kepentingan publik dapat didefinisikan sebagai ruang publik. Jadi dalam konteks ini, RPTRA merupakan dari ruang publik. Konsensus menjadi aspek pengendali bukan individu atau sekelompok tertentu, baik tirani mayoritas maupun dominasi minoritas.

Ketiga, ruang publik merupakan ruang yang terbuka dan aksesibel secara visual maupun fisik bagi semua tanpa kecuali. Sebuah ruang publik harus terbuka bagi semua orang dari latar belakang tanpa perkecualian. Dalam hal ini ruang publik, keberadaannya seperti public goods yang pemanfaatan dan penggunaannya tidak 
bisa menafikan pihak lain. Terakhir karaktersitik keempat yaitu ruang publik merupakan ruang yang mana masyarakat mendapat kebebasan beraktivitas. Semangat yang menyelimuti ruang publik yaitu kebebasan ekspresi dan aktualisasi diri,akan tetapi karena karakteristik yang publik maka kebebasan tersebut tidak berlaku mutlak, selalu ada batasan terhadap kebebasan yang lain.

\section{b. Demokrasi Deliberatif}

Keterlibatan masyarakat dalam berpartisipasi merupakan inti dari demokrasi deliberatif. Demokrasi deliberatif berbeda dengan demokrasi perwakilan, yang hari ini berlaku di Indonesia yang malah menjadi demokrasi prosedural semata. Gagasan keterlibatan masyarakat yang emansipatif merujuk pada proses komunikasi serta pencapaian konsensus di dalam forum-forum yang diselenggarakan di ruang publik di mana para partisipan didesak untuk melakukan proses komunikasi secara terbuka, setara dan menggunakan pendekatan musyawarah dalam mencapai sebuah kesepakatan yang menghargai opini mayoritas maupun minoritas. Lebih lanjut, praktik dalam proses tim penyusun kebijakan publik maupun dalam proses publik harus mengedepankan prinsip kesetaraan serta keterbukaan dalam proses komunikasinya, agar mampu terselenggara proses musyawarah yang fair. Melalui adanya keseimbangan dalam hak dan otoritas baik dari ahli, birokrasi, komisi legislatif dan masyarakat dalam forum-forum tersebut, maka akan tercipta komunikasi yang setara. Misal, saat terdapat satu pihak yang masih belum setuju, katakanlah masyarakat, maka forum proses publik tidak mampu dilanjutkan dan kesepakatan standar pelayanan publik tidak mampu disahkan oleh pejabat yang berwenang. Di sini, terdapat keseimbangan relasi kekuasaan, yang pada akhirnya akan mendesak orientasi dari para partisipan forum untuk mengedepankan kepentingan bersama, atau hal-hal yang lebih luas dari selfinterest maupun group-interest nya masing-masing.

Pemikiran Jurgen Habermas tentang tindakan komunikatif serta nalar berorientasi konsensus menjadi landasan teoritis dalam penelitian ini, di mana Habermas menilai bahwa proses komunikasi harus setara demi tercapainya kesepakatan yang mampu diterima seluruh pihak, atau dengan kata lain, Habermas melihat integrasi sosial hanya mampu dicapai melalui proses tindakan komunikatif yang berujung pada pencapaian konsensus. Dalam hal ini, Habermas mencatat bahwa tindakan komunikatif harus dimaknai sebagai,

"...reach understanding [verstandigung] is considered to be a process of reaching agreement [einigung] among speaking and acting subjects... it has to be accepted or presupposed as valid by participants... a communicatively achieved agreement has a rational basis; it cannot be imposed by either party, whether instrumentally through intervention in the situation directly or strategically 
through influencing the decision of opponents..." (Habermas 1984)

Melalui kesepemahaman antara subjek atau partisan dalam forum sebuah tindakan komunikatif mampu berjalan, tetapi saat terjadi pemaksaan dan kebohongan, maka tindakan komunikatif berubah menjadi tindakan strategis dan instrumental yang tidak akan berujung pada konsensus, melainkan penguasaan dan pemenuhan ambisi atau tujuan-tujuan pribadi (self-interest). Seperti yang disinggung secara implisit ruang publik memiliki fungsi signifikan, yakni sebagai ruang di mana opini publik yang otentik, kritisme masyarakat terhadap kekuatan politik maupun ekonomi demi mencapai keseimbangan dan keadilan sosial, dapat terbentuk dan tersebar luas kepada seluruh warga negara, sekaligus sebagai penekan terhadap segala bentuk manipulasi ruang publik. Manipulasi ruang publik ini lah yang harus "diwaspadai" oleh para peserta musyawarah.

Budi Hardiman (1991) menyatakan, “...Habermas menempuh jalan konsensus dengan sasaran terciptanya demokrasi radikal yaitu hubungan sosial yang terjadi dalam lingkup komunikasi bebas penguasaan." Dengan kata lain Habermas menggunakan pendekatan komunikatif yang diharapkan mambangun masyarakat serta sistem sosial komunikatif. Dalam hal ini kembali Budi Hardiman (1993) menjelaskan masyarakat komunikatif bukanlah masyarakat yang melakukan kritik lewat revolusi dengan kekerasan, melainkan lewat argumentasi. Berbeda dengan Marx yang menganalsa perkembangan masyarakat akan terjadi melalui revolusi yang kemudian masyarakat akan terbebaskan dari belenggu penindasan, Habermas justru menawarkan alternatif lain yaitu paradigma komunikatif yang bebas penguasaan, agar perubahan masyarakat tidak lagi melahirkan tirani baru, tidak melahirkan penindasan baru. Dalam konsepsi masyarakat komunikatif, Habermas menekankan pada terciptanya ruang dialogal yang bebas dari dominasi atau penguasaan satu pihak dengan tujuan agar terciptanya konsensus di tengah masyarakat.

Dalam komunikasi menurut Habermas, setiap komunikator ingin membuat lawan bicaranya memahami maksudnya dengan berusaha mencapai apa yang disebutnya klaim-klaim kesahihan (validity claims), yang terdiri dari; pertama, klaim kebenaran (claim of truth) yaitu ketika kita sepakat kepada dunia alamiah dan objektif. Kedua, klaim ketepatan (claim of rightness), kala kita sepakat pada pelaksanaan norma-norma dalam kehidupan sosial. Ketiga, klaim kejujuran (claim of sincerity) yaitu kalau kita sepakat tentang kesesuaian antara bathiniah dengan ekspresi seseorang. Keempat, klaim komprehensibilitas (claim of comprehensibility) jika kita sepakat dan mampu menjelaskan ketiga klaim sebelumnya. Komunikasi yang efektif melibatkan keempat klaim tersebut karena 
merupakan standar kompetensi komunikatif (Sunarto 2000).

Kesetaraan menjadi prakondisi yang harus ada sebelum terciptanya konsensus. Setiap orang yang menjadi peserta demokrasi memiliki kesempatan yang sama untuk menyampaikan opini dan gagasannya, memberi tanggapan baik dari mulai mengkritik atau menerima terhadap suara partisipan lain. Sehingga setiap pernyataan yang muncul telah masuk dalam telaah kritis. Semua ini bisa menjadi tindakan komunikatif bila tanpa ada pengaruh yang berasal dari dominasi pihak-pihak tertentu baik yang bersifat terbuka ataupun tertutup karena bila ruang publik direbut oleh pihak-pihak tertentu yang mendominanasi, maka keputusan yang menjadi hasil hanya sekedar menjadi ketundukan. Alih-alih ruang publik malah menjadi ruang dominasi.

Hal yang bisa dilakukan agar subjeksubjek partisipan terbebas dari berbagai pengaruh kelas atau pihak yang mendominasi ruang publik, maka diperlukan sebuah kondisi dialogis, hubungan intersubjektif yang berkelanjutan dan bebas dari dominasi. Oleh karena itu rasio atau kesadaran manusia bukan lagi sebagai rasio bertujuan, yang intrumentalis melainkan menjadi rasio komunikatif, yang mana rasio senantiasa menguji dirinya dalam suasana dialogis. Maka dengan langkah itu semua konsensus sejati bisa tercipta.

\section{c. Menelusuri yang Publik dari RPTRA} Seperti yang dijelaskan sebelumnya, pembangunan RPTRA dibiayai melalui CSR, oleh karenanya pasar begitu berperan dalam pembangunan ruang untuk publik. Hal ini menarik untuk bisa diproblematisir dalam membaca kemungkinan potensi kepublikan yang ada dalam proses pembangunan (dan pengelolaan) RPTRA. Pada kesempatan ini peneliti akan mencoba mengelaborasi dan fokus pada diskursus yang muncul dan tersebar selama proses pembangunan dan pengelolaan RPTRA selama ini.

RPTRA Sunter Jaya Berseri dibangun atas dasar keinginan warga sekitar yang berharap di wilayah mereka terdapat ruang terbuka atau taman yang bisa dijadikan lokasi bermain bagi anak-anak atau tempat berkumpul warga. Hal ini pun diakui langsung oleh beberapa informan dari warga yang peneliti temui. Mereka mengemukakan sebelumnya memang warga memiliki aspirasi agar ada tempat bermain bagi anak-anak. Kebijakan melalui program pembangunan RPTRA menjadi titik temu antara harapan warga dengan program pemerintah.

Adapun lokasi yang akhirnya dipilih dijadikan RPTRA adalah di di Jalan Bentengan 6 No 1, RT 06/05, Kelurahan Sunter Jaya, Kecamatan Tanjung Priok, Jakarta Utara yang mana lahan tersebut persis bersebelahan dengan Kantor Kelurahan Sunter Jaya. Luas lahan yang dijadikan RPTRA Sunter Jaya Berseri seluas $2.200 \mathrm{~m}^{2}$. Lokasi tersebut dulunya 
merupakan lahan yang kurang terawat sehingga sering dijadikan pasar malam yang membuat lahan tersebut terkesan kotor dan kumuh. Menurut pengelola, kondisi demikian yang mendorong warga untuk mengusulkan agar lahan tersebut menjadi RPTRA. Atas kerjasama Pemprov DKI Jakarta dengan PT Astra International Tbk melalui CSR, akhirnya lokasi tersebut berhasil merubah wajah taman menjadi lebih hijau dan asri. RPTRA Sunter Jaya Berseri dilengkapi berbagai fasilitas, diantaranya seperti taman baca, sarana bermain, open theatre, ruang berkumpul, PKK Mart, ruang laktasi sampai lapangan untuk bulu tangkis.

Sedangkan RPTRA Sungai Bambu berlokasi di Jalan Jati Raya RW 06, Kelurahan Sungai Bambu, Kecamatan Tanjung Priok, Jakarta Utara. Lokasi RPTRA persis di bawah Jalan layang tol yang menghubungkan Cawang dengan Tanjung Priok. Adapun luas lahan sebesar $3.832 \mathrm{~m}^{2}$. RPTRA Sungai Bambu merupakan hasil kerjasama antara Pemprov DKI Jakarta dengan perusahaan sebagai manifestasi dari CSR, di antaranya yaitu PT Astra International Tbk, PT Pembangunan Jaya dan PT Citra Marga Nusaphala Persada (CMNP).

Analisa Habermas tentang ruang publik yang berjarak dengan pasar dan pemerintah memiliki konsekuensi logis sebagai prasyarat untuk lahir dan berkembangannya otonomi publik dalam menyampaikan gagasan dan aspirasinya.
Namun realitasnya, pendambaan ruang publik yang dikehendaki Habermas sulit menemukan realisasinya. Karena ruang publik tidak berada dalam ruang yang vakum, manuver politik dan pasar akan selalu menyelimuti ruang-ruang publik. Dalam konteks inilah agenda penting bagi publik lahir, yaitu bagaimana publik dapat mengamankan karakter kepublikan yang melekat dalam ruang publik. Sejauh ini, walaupun pada awal proses pembangunan RPTRA warga tidak terlibat dalam tahap perencanaan secara menyeluruh, namun proses pengelolaan RPTRA melibatkan warga sekitar. Seperti perawatan taman yang dilakukan oleh warga di sekitar RPTRA dan dikoordinir oleh ibu-ibu PKK. RPTRA memposisikan warga sebagai pemilik dan pengelola taman, bukan sekadar penikmat taman. Kerjakerja "teknis" seperti ini penting untuk merawat kepublikan dari ruang publik karena dari kerja-kerja kecil yang dilaksanakan oleh warga bisa menciptakan rasa kepemilikan kepada ruang publik yang secara perlahan berbroses untuk berpikir dan bertindak bagaimana menjaganya.

Proyek pembangunan RPTRA bisa menjadi elemen yang penting dalam memajukan peradaban kota seperti DKI Jakarta. Karena dari ruang inilah kerekatan sosial dan modal sosial antar warga berpotensi bisa diperkuat dengan akumulasi interaksi. Harapannya warga yang tercerai berai merekat menjadi civil society. Namun seperti yang sudah diingatkan oleh Foucault, ruang akan 
selalu mengerucut pada hal yang paling mendasar dari praktik kekuasaan. Begitupula yang disampaikan oleh Henri Levebre bahwa ruang adalah produk sosial yang dinamis dan dibentuk oleh orang-orang yang memiliki kontrol dan tentu saja dominasi atas kekuasaan (Bima 2013). Permasalahan klasik terkait ruang publik di Indonesia, khususnya DKI Jakarta adalah ruang ruang publik yang kerapkali dikuasai oleh segelintir pihak tertentu. Ruang publik malah diperebutkan dan sering dikomersialkan. Misal ada Pantai Ancol yang mana warga harus membayar untuk menikmati ruang pantai. Jalur pejalan kaki di kota-kota besar yang diambil alih oleh perusahaanperusahaan besar properti. Dari case by case ini maka tidak heran warga tidak bisa mengerti dan menghargai esensi dan pentingnya sebuah ruang publik.

Pembangunan RPTRA pun sebenarnya berpretensi demikian walaupun dengan rupa yang tidak sama. Problem laten dan mendasar dari CSR adalah selalu menjadi proyek pembangunan yang dijalankan suatu perusahaan untuk mengganti kerugian sosial dan ekonomi masyarakat setempat. Melalui kegiatan CSR, perusahaan lalu memperoleh legitimasi atas aktivitas bisnisnya. Dampak lebih jauh dari kegiatan CSR ini, masyarakat lalu berpikir bahwa kebutuhan atas pendidikan, air bersih, kesehatan, merupakan tanggung jawab perusahaan, bukan tanggung jawab negara (Fanimbang 2011). Dengan kata lain ada istilah no free luch dalam logika CSR atau semacam politik etis dalam etika kapitalisme. Karena pada ujungnya CSR digunakan untuk menjaga nama baik dan citra perusahaan. Kritik ini menjadi pertimbangan dalam menganalisa potensi demokrasi deliberatif pada RPTRA di Sungai Bambu dan Sunter Jaya.

Kritik tersebut tidak ditujukan menjadi tendesius dan justru tetap relevan agar tetap menjaga fungsi negara, dalam hal ini pemerintah, untuk memberikan hak-hak yang yang laik diberikan kepada warganya tanpa menyerahkan begitu saja kepada mekanisme pasar melalui CSR. Apakah setelah CSR berjalan, wacana kepublikan menjadi memudar? Sehingga warga merasa bahwa yang berperan besar dalam pembangunan RPTRA ini adalah pihak swasta, alih-alih inisiatif dan praktik dari pemerintah.

Dalam kesempatan ini peneliti mencoba melakukan observasi terkait bagaimana wacana hal ihwal yang publik yang hadir dalam (pembangunan) pengelolaan RPTRA di dua lokasi penelitian. Seperti disinggung sebelumnya, RPTRA merupakan program hasil kolaborasi dari pemerintah dan pihak swasta. Di atas kertas, tidak ada yang permasalahan terkait dengan konsep kolaborasi tersebut, bahkan secara regulasi mengamanatkan demikian. Dalam mewujudkan Kota Layak Anak (KLA), salah satu indikator dari Peraturan Menteri Negara Pemberdayaan Perempuan dan Perlindungan Anak Republik Indonesia pasal 6 hurup (g) yaitu perlunya 
keterlibatan dunia usaha dalam pemenuhan hak anak. Namun catatan tersebut, jangan sampai melupakan "publik" dari ruang publik tersebut. Dari hasil penelitian melalui wawancara dengan beberapa informan serta pengamatan langsung dan observasi lapangan, bila dilihat dalam perspektif demokrasi deliberatif, peneliti menemukan hadirnya konsekuensi logis dari sebuah program "top down". Peneliti menggunakan tanda petik (") dalam topdown, karena pada implementasinya warga tidak terlibat terlalu jauh dalam proses pembangunan RPTRA. Memang, pada dasarnya RPTRA diperuntukkan bagi publik atau warga sekitar agar bermanfaat serta menjadi ruang interaksi antar warga. Sebagaimana yang diungkap sebelumnya oleh Gubernur DKI Jakarta saat itu, Ahok, bahwa RPTRA adalah inisiasi untuk memperluas ruang terbuka (hiijau) bagi warga. Pada saat pembukaan RPTRA Sunter Jaya saat itu, Ahok mengungkapkan, "Memang saat ini keberadaan ruang berkumpul masyarakat di DKI Jakarta, dari janin hingga ibu-ibu belum ada. Maka dari itu Pemprov DKI Jakarta berkomitmen terus membangun dan memperbanyak ruang terbuka hijau, salah satunya RPTRA. Saya berharap adanya RPTRA ini akan sangat bermanfaat bagi warga," Statmen ini menjadi hal yang penting sebagai dasar untuk melihat secara lebih dalam bagaimana praktik implementasi (selanjutnya) dan konsistensi pemerintah dalam membangun RPTRA. Lokasi RPTRA Sungai Bambu dan RPTRA
Sunter Jaya dipilih langsung hasil dari rembug warga yang difasilitasi oleh kelurahan setempat. "Yang memilih tempat untuk jadi RPTRA di sini (Sunter Jaya) adalah dari warga langsung," ungkap satu informan dari pihak Kelurahan Sunter Jaya saat peneliti temui. Begitupula RPTRA Sungai Bambu.

Satu informan dari salah satu warga sekitar RPTRA Sungai Bambu mengkonfirmasi bahwa terkait pemilihan lokasi merupakan hasil dari musyawarah warga. Hal menarik dari RPTRA Sungai Bambu yang berada tepat di bawah Jalan layan tol yang menghubungkan Cawang dan Tanjung Priok, tepatnya di Jalan Jati Raya RW 06 Kelurahan Sungai Bambu, Kecamatan Tanjung Priok ini dulunya merupakan lahan kosong yang tidak terawat yang dipenuhi semak belukar.

Pemilihan lokasi dilakukan atas masukan langsung dari warga, sedangkan proses pembuatan RPTRA dilaksanakan oleh pihak swasta, dari mulai perancangan sampai ke tahap pembangunan. Hal inilah yang menjadi sedikit kelemahan dari RPTRA bila ditinjau dalam perspektif demokasi deliberatif. Karena saat proses pembangunan, warga yang mana memiliki "kedaulatan" atas lahan publik tersebut tidak terlibat secara aktif. Secara tidak langsung, warga menyerahkan haknya atas ruang terbuka hijau kepada pihak swasta. Namun karena RPTRA merupakan program yang sudah tersusun rapi yang melibatkan pihak-pihak profesional, maka di lapangan, ketidak- 
terlibatan warga secara aktif dalam proses pembangunan tersebut tidak menjadi "masalah besar" secara ontologis.

Ketidak-terlibatan secara aktif warga saat proses pembangunan RPTRA masih reasonable mengingat biaya yang dibutuhkan tidak sedikit. Misalnya, untuk pembuatan RPTRA Sungai Bambu melibatkan beberapa perusahaan. PT Pembangunan Jaya dengan dana CSR sebesar Rp. 412.154 .795 (empat ratus dua belas juta seratus lima puluh empat ribu tujuh ratus sembilan puluh lima rupiah), PT Citra Marga Nushapala Persada dengan dana CSR Rp. 220.000.000,- (dua ratuh dua puluh juta rupiah), dan PT Toyota Motor Manufacturing Indonesia dengan dana sebesar Rp. 87.664.000,(delapan tujuh puhuh juta enam ratur enam puluh empat ribu rupiah). Angka tersebut tentu cukup besar bila warga harus terlebih dahulu patungan membiayai pembangunan tersebut. Oleh karenanya dana CSR bisa mengakselererasi pembangunan RPTRA.

Selain soal nominal, ketidak-terlibatan secara aktif warga selama proses pembangunan RPTRA karena faktor sumber daya manusia. Tidak semua warga memahami hal yang berkaitan dengan arsitektur. Seperti yang diungkap langsung oleh Ahok, "Saya memang sering minta sama pengusaha untuk membangun proyek-proyek semacam ini, karena mereka jauh lebih profesional dalam proses pembangunan gedung dan infrastruktur"

(www.beritajakarta.id 2017).

Namun bila soal keterlibatan warga dalam pembangunan RPTRA ini direduksi nilai deliberatifnya, misal keterlibatan dalam sosialisasi, maka hal tersebut memang terlaksana. Pemerintah Provinsi DKI Jakarta mengenalkan proram RPTRA ini melalui sosialisasi dengan Focus Group Discussion (FGD) bersama para warga. Proses FGD dilakukan sebelum pembangunan RPTRA untuk mengidentifikasi kebutuhan-kebutuhan warga yang bisa dipeloleh melalui hadirnya RPTRA. Baik di Sungai Bambu maupun di Sunter Jaya, pemerintah setempat sempat melaksanakan sosialisasi kepada warga terkait rencana akan dibangunnya RPTRA. Akan tetapi demokrasi deliberatif tentunya sama sekali tidak bisa diinterpertasikan menjadi sebatas sosialisasi.

Dalam demokrasi deliberatif mengandaikan kesepemahaman antara subjek atau partisan dalam sebuah forum yang berlandaskan pada tindakan komunikatif, sedangkan sosialisasi tidak memenuhi syarat persamaan posisi karena tentunya pihak pemerintah setidaknya pasti sudah memiliki tujuan yang mengarahkan agar warga mengikuti sesuai dengan apa yang dikehendaki mereka.

Selanjutnya, untuk kembali menelusuri hal ihwal yang publik dari RPTRA, peneliti melakukan analisis berdasarkan pada karakter ruang publik yang 
diargumentasikan oleh Sunaryo et al., (2010). Pertama ruang publik merupakan tempat berinteraksi masyarakat. Hasil temuan menunjukan baik di RPTRA Sunter Jaya maupun RPTRA Sungai Bambu telah berhasil menjadi ruang bersama para warga sekitar. Interaksi sosial tercipta. Hal ini disebabkan karena lokasi dari RPTRA sendiri yang unik, berada tepat di tengah pemukiman warga. Sehingga warga memiliki akses yang sangat mudah untuk berkunjung ke RPTRA. Warga dari kategori usia anakanak sampai lansia berinteraksi dan bersosialisasi di RPTRA.

Kedua, ruang publik diadakan, dikelola dan dikontrol secara bersama, baik oleh negara atau privat, yang didedikasikan untuk kepentingan publik. Karakter ini relevan dengan RPTRA yang diadakan oleh negara dengan pihak swasta untuk kepentingan publik. Sedangkan pengelolaannya dilaksanakan langsung oleh warga sekitar. Dengan segala dinamikanya, warga sekitar RPTRA secara otonomi relatif (karena telah ada regulasi yang mengatur) telah melakukan kontrol terhadap ruang publiknya. Warga sangat mendukung penuh terhadap proyek RPTRA ini, secara perlahan namun pasti warga memiliki rasa kepemlikian terhadap ruang publik mereka.

Selanjutnya ketiga, ruang publik merupakan ruang yang terbuka dan aksesibel secara visual maupun fisik bagi semua tanpa kecuali. Kriteria ruang publik ini kembali relevan bagi konteks
RPTRA. Tidak ada tiket untuk berkunjung ke RPTRA, siapapun boleh datang tanpa terkecuali. Walaupun bukan warga sekitar Sungai Bambu maupun Sunter Jaya, kedua RPTRA terbuka untuk dikunjungi siapa saja. Bahkan tidak sedikit intitusi dari luar datang untuk menyelenggarakan kegiatan di RPTRA Sungai Bambu maupun RPTRA Sunter Jaya. Karakter keempat, ruang publik merupakan ruang yang mana warga mendapat kebebasan beraktivitas.

Sampai saat ini, warga mendapatkan kebebasan untuk melakukan berbagai aktivitas positif. Namun, tentunya kebebasan tersebut tidak bisa bersifat mutlak, karena bagaimanapun RPTRA dibangun untuk wahana bermain yang nyaman bagi anak-anak dan ruang keluarga, sehingga kegiatan-kegiatan yang bisa menggangu hak anak-anak tidak bisa dilakukan di RPTRA. Kegiatan seperti kampannye partai, aktivitas politik praktis, event yang menyediakan stand perusahaan rokok, dll dilarang di RPTRA. Pada dasarnya, semangat yang menyelimuti ruang publik tak lain adalah kebebasan berekspresi dan aktualisasi, namun selalu ada batasan terhadap kebebasan pihak lain, begitupula RPTRA yang dibatasi oleh fungsinya. 
Tabel 1. Karakteristik Ruang Publik di RPTRA Sunter Jaya dan RPTRA Sungai Bambu

\begin{tabular}{|c|c|c|}
\hline $\begin{array}{c}\text { Karakter } \\
\text { Ruang Publik }\end{array}$ & $\begin{array}{c}\text { RPTRA } \\
\text { Sunter Jaya }\end{array}$ & $\begin{array}{l}\text { RPTRA } \\
\text { Sungai } \\
\text { Bambu }\end{array}$ \\
\hline $\begin{array}{l}\text { Tempat } \\
\text { berinteraksi } \\
\text { masyarakat }\end{array}$ & Ya & $\mathrm{Ya}$ \\
\hline $\begin{array}{l}\text { Diadakan, } \\
\text { dikelola dan } \\
\text { dikontrol } \\
\text { bersama yang } \\
\text { didedikasikan } \\
\text { untuk } \\
\text { kepentingan } \\
\text { publik }\end{array}$ & Ya & Ya \\
\hline $\begin{array}{l}\text { Ruang yang } \\
\text { terbuka dan } \\
\text { aksesibel bagi } \\
\text { semua }\end{array}$ & Ya & Ya \\
\hline $\begin{array}{l}\text { Warga mendapat } \\
\text { kebebasan } \\
\text { beraktivitas }\end{array}$ & Relatif & Relatif \\
\hline
\end{tabular}

Sumber: Data diolah Peneliti (2017)

\section{d. Jejak Partisipasi Publik}

Sebagai ruang publik, RPTRA perlu memposisikan publik sebagai pusat, tidak hanya sebagai penikmat atau pengguna. RPTRA Sungai Bambu merupakan pilot project RPTRA yang pertama kali dibangun Pemprov DKI Jakarta. Begitupula RPTRA Sunter Jaya Berseri adalah proyek lanjutan pembangunan RPTRA yang dibiayai oleh CSR. Oleh karenanya analisa yang dilakukan tidak bisa lepas dari konteks proyek tersebut pada awalnya lebih dominan bersifat top down.

RPTRA adalah hasil dari kebijakan publik yang mengkondisikan relasi antara negara dan warganegara. Di antara relasi tersebut tercipta irisan yang disebut sebagai partisipasi. Irisan dari relasi tersebut menciptakan dinamika interaksi antara warga negara dengan administrasi publik yang semakin hari semakin berkembang/berevolusi. Proses awal evolusi, posisi citizens as subjects dan public administration as rulers, bergeser ke arah citizens as voters dan public administration as trustees, lantas bergeser lagi ke arah citizens as clients/costumer dan public administration as managers, selanjutnya citizens as partners dan public administration as partners, terakhir, citizens as owners dan public administration as subjects (Kumorotomo 2007). Pada titik inilah, warga negara sebagai pemilik memiliki konsekuensi kedaulatan. Oleh karenanya, pendekatan top down dalam proyek pembangunan RPTRA sebenarnya menjadi kurang relevan.

RPTRA sebenarnya bisa diartikulasikan sebagai ruang publik dalam bentuk musyawarah bersama yang melibatkan seluruh elemen stakeholders, baik dalam bentuk material maupun immaterial. Dalam bentuk material hal yang dilakukan adalah dengan menyelenggarakan dialog bersama, tidak hanya pemerintah dengan perusahaan tapi juga warga untuk menentukan standar pembangunan dan pengelolaan RPTRA. Tindakan komunikatif tersebut terus digalakan sampai konsensus tercapai. Jadi proses analisis pembangunan RPTRA harusnya tidak lagi dilakukan hanya oleh para teknokrat atau para profesional semata, melainkan semua pihak yang terlibat 
langsung (Faedlulloh 2015). Akan tetapi, seperti dijelaskan sebelumnya, warga ternyata tidak terlibat secara aktif pada saat proses pembangunan, namun hal tersebut tidak lantas menggambarkan kondisi RPTRA minim partisipatif dalam semua hal. Karena setelah RPTRA selesai dibangun, warga langsung merasakan manfaat dari RPTRA tersebut. Hal ini yang kemudian mendorong publik secara altruis untuk berpartisipasi dalam menjaga dan merawat RPTRA.

Partisipasi publik yang terlaksana dalam pengelolaan RPTRA di Sungai Bambu dan Sunter Jaya adalah pada proses pemanfaat ruang publik. Walaupun para pengelola direkrut secara profesional, dengan diawali informasi pembukaan rekruitmen "lowongan kerja" namun pada praktiknya masing-masing kelurahan mengutamakan sumber daya lokal, yakni warga sekitar untuk menjadi pengelola tetap. Proses perekrutan pengelola melalui tahap fit and proper test yang dilaksanakan oleh tim penilai yang ditunjuk langung oleh TP PKK DKI Jakarta. Ada banyak kriteria, bagi yang telah memenuhi kriteria akan diangkat menjadi pengelola RPTRA dengan stausus Petugas Harian Lepas (PHL). Dalam kesempatan ini, peneliti tidak melakukan penelusuran kinerja pengelola, namun bagaimana terciptanya hubungan dialektis antara warga dengan pengelola RPTRA yang menjadi berjalan harmonis. Segala aktivitas warga kini dipusatkan di RPTRA dari mulai kumpulan PKK sampai dengan komunitas pemuda di sekitar Kelurahan Sungai Bambu dan Sunter Jaya. Setiap hari RPTRA Sunter Jaya dan RPTRA Sungai Bambu selalu ramai oleh warga, dari pagi sampai sore hari. Bahkan ada jadwal khusus dalam penggunaan dan pemanfaatan RPTRA untuk komunitas-komunitas sekitar RPTRA.

Untuk pengelolaan ruang publik maka diperlukan kontrol dan regulasi yang disepakati secara konsensus termasuk bila di dalamnya perlu regulasi dalam hal pembiayaan perawatan. Untuk regulasi, pembiayaan merujuk pada Peraturan Gubernur Provinsi Daerah Khusus Ibukota Jakarta Nomor 196 Tahun 2015 pasal 29, yakni dibiayai dari APBD atau sumber dana lain yang sah (enam bulan pertama dibiayai oleh CSR). Akan tetapi untuk menjaga dan merawat ruang publik memerlukan sumberdaya lain dalam pemeliharaannya. Pada konteks inilah partsipasi warga begitu berperan dalam pengelolaan dan perawatan RPTRA.

Partisipasi tidak sebatas aktivitas fisik, namun juga melibatkan mental dan emosional orang-orang pada situasi kelompok untuk memberikan kontribusi untuk mencapai tujuan kelompok (Davis \& Newstrom 2007). Hal menarik dari konsepsi yang digagas Davis dan Newstrom ini adanya keterlibatan mental dan emosi seseorang. Keterlibatan mental warga akan ikut andil dalam proses pengelolaan dan perawatan ruang publik, tak terkecuali RPTRA. Hal inilah yang peneliti temui di RPTRA, baik Sungai 
Bambu maupun Sunter Jaya. Rasa kepemilikan warga terhadap RPTRA-nya begitu tinggi, sehingga "dengan sendirinya" para warga ikut andil tanpa perlu ada aturan yang mengikat mereka. Situasi ini ditunjukan dengan aktivitas bersih-bersih yang dilakukan warga sebagai bagian dari perawatan RPTRA yang dilakukan secara rutin perbulannya. Selain itu, warga sekitar pun berpartisipasi secara ekonomi. Dalam setiap kegiatan yang dilaksanakan di RPTRA para warga sekitar RPTRA melakukan swadaya dalam mengumpulkan anggaran.

Berdasarkan beberapa penjelasan di atas menunjukan RPTRA merupakan situs transformasi demokrasi deliberatif. Saat proses pembangunan RPTRA, demokrasi deliberatif belum menjadi dasar karena aktor yang banyak berperan adalah swasta dan pemerintah. Sedangkan pada proses pengelolaan RPTRA, warga (bukan hanya pengelola) secara altruis sudah mulai terlibat aktif dan merasakan langsung manfaat dari proyek pembanguna RPTRA. Rasa kepemilikan menghasilkan partisipasi, partisipasi menciptakan pemberdayaan bagi warga. Secara tidak lansung, ramainya RPTRA memberikan manfaat bagi para pelaku usaha kecil menengah yang berada di sekitar RPTRA sehingga berimbas pada kesejahteraan mereka. Untuk menggambarkan hasil dari transformasi demokrasi deliberatif tersebut bisa dilihat dari diagram berikut:

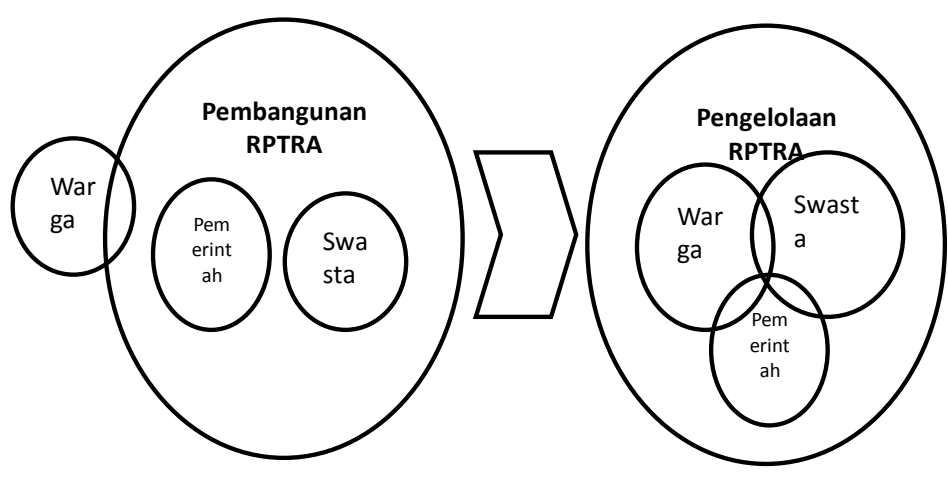

Gambar 1. Diagram Transformasi

Deliberasi pada Pembangunan dan Pengelolaan RPTRA

Sumber: Hasil Penelitian Peneliti (2017)

Demokrasi partisipatif memerlukan struktur pembuatan keputusan yang terdesentralisasi, dan desentralisasi merupakan unsur utama dari suatu visi alternatif untuk melakukan perubahan dari bawah (Ife \& Tesoriero 2008). Untuk lebih meradikalkan demokrasi deliberatif yang menyelimuti RPTRA, maka perlu penekanan pada asas desentralisasi ini kepada publik, agar publik benar-benar dalam posisi yang setara dengan pihak pemerintah dan swasta, bahkan bisa menjadi ruang untuk beradu opini dengan pihak pemerintah dan swasta. Di luar konteks lokasi peneltian, misal dari kasus hadirnya salah satu anak perusahaan rokok (bli-bli.com anak perusahaan dari PT Djarum) yang menjadi sponsor dari proyek RPTRA sempat menjadi sorotan tersendiri di awal-awal implementasi RPTRA. Dengan hal ini publik berusaha merebut ruang publik agar tidak didominasi oleh kepentingan perusahaan semata. 


\section{Kesimpulan}

RPTRA telah menjadi ruang yang terbuka dan aksesibel bagi semua orang tanpa kecuali. RPTRA Sungai Bambu dan RPTRA Sunter Jaya Berseri secara perlahan menjadi ruang yang demokratis dan tempat bersua khalayak banyak. Kedua lokasi tersebut memenuhi karakter dari ruang publik. Keberadaannya di wilayah yang dekat dengan pemukiman warga, khususnya warga miskin adalah bentuk affirmative action yang layak diapresiasi di tengah banyak ruang-ruang hak publik yang justru dinikmati secara ekslusif oleh segelintir pihak. RPTRA bisa menjadi ruang bagi warga untuk berinteraksi dan belajar bertoleransi terhadap perbedaan, kemudian tidak menutup kemungkinan menjadi tempat warga berlatih menghadapi kejutankejutan sosial yang mungkin muncul.

Kehadiran RPTRA adalah inovasi Pemprov DKI Jakarta yang layak diapresiasi di tengah menyempitnya ruang gerak warga Jakarta karena dampak pembangunan komersil. RPTRA dapat merubah wajah Ibu Kota menjadi lebih ramah terhadap anak-anak. RPTRA adalah menifestasi ruang publik yang tidak semata sebagai sarana berkumpul dan bermain anak-anak tapi juga berpotensi berperan menjadi melting pot warga dengan berbagai latar belakang yang heterogen dan menjadi katalisator ragam kegiatan masyarakat, dari mulai aktivitas sosial, budaya bahkan rekreasi keluarga. RPTRA mengakomodasi interaksi sosial. Bila hal ini berlangsung secara berkelanjutan dapat mendorong pembelajaran bagi masyarakat untuk saling mengerti satu sama lain, ruang dialogal, ruang berbagi antara komunitas yang berbeda, sehingga potensi demokrasi deliberatif pun bisa menjadi lebih kuat untuk menjadi jangkar dalam menjaga dan merawat RPTRA. Sampai pada waktunya, seperti dari hasil penelitian yang menunjukan adanya kekurangan (lack) demokrasi deliberatif pada proses pembangunan, bisa ditutup oleh kekuatan publik sendiri yang memilih jalan partisipasi langsung yang bebas dari dominasi dan penguasaan satu pihak tertentu. Sehingga RPTRA bisa tetap berjalan sebagaimana mestinya.

\section{Daftar Pustaka}

Bima, W., 2013. Merebut Kuasa atas Ruang Publik: Pertarungan Ruang Komunitas Mural di Surabaya. Available at: http://repository.petra.ac.id/16179/1/ Publikasi1_02032_1056.pdf.

Davis, K. \& Newstrom, J., 2007. Perilaku dalam Organisasi, Jakarta: Erlangga.

Eley, G., 1992. Nations, Publics, and Political Cultures: Placing Habermas in the Nineteenth Century' Habermas and the Public Sphere, London: The MIT Press, 1992. In C. Calhoun, ed. Habermas and the Public Sphere. London: The MIT Press.

Faedlulloh, D., 2015. Local Public Sphere for Discursive Public Service in Indonesia: Habermas Perspective. European Journal of Social Sciences Education and Research, 5(1), pp.427-432.

Fanimbang, P., 2011. Tanggung Jawab Sosial Persuhaan Sebuah Kritik. Indoprogress. 
Habermas, J., 1992. Further Reflections on the Public Sphere. In C. Calhoun, ed. Habermas and the Public Sphere. The MIT Press, p. 42.

Habermas, J., 1964. The Public Sphere: An Encyclopedia Article, New German Critique3 (Autumn/1974).

Habermas, J., 1984. The Theory of Communicative Action: Reason and The Rationalization of Society. Volume I, Boston: Beacon Press.

Hardiman, B., 1991. Kritik Ideologi; Menyingkap Pertautan Pengetahuan dan Kepentingan Bersama Jurgen Habermas, Yogyakarta: Kanisius.

Hardiman, B., 1993. Menuju Masyarakat Komunikatif: Ilmu, Masyarakat, Politik dan Posmodernisme Menurut Jürgen Habermas, Yogyakarta: Kanisius.

Ife, J. \& Tesoriero, F., 2008. Community Development: Alternatif Pengembangan Masyarakat di Era Globalisasi, Yogyakarta: Pustaka Pelajar.

Kadarsih, R., 2008. Demokrasi dalam Ruang Publik. Jurnal Dakwah. Vol IX No. 1 Januari-Juni 2008. Jurnal Dakwah, Vol IX(No. 1).

Kumorotomo, W., 2007. Citizen Charter (Kontrak Pelayanan): Pola Kemitraan Strategis Untuk Mewujudkan Good Governance Dalam Pelayanan Publik. Seminar Persadi.

Moleong, L.J., 2004. Metode Penelitian Kualitatif, Bandung: PT. Remaja Rosdakarya.

Sunarto, 2000. Pers Mahasiswa: Persemaian Public Sphere Civil Society. In Forum Komunikasi Pers Mahasiswa Indonesia pada tanggal 21 Okteober 2000.

Sunaryo et al., 2010. Posisi Ruang Publik dalam Transformasi Konsepsi Urbanitas Kota Indonesia. In: Seminar Nasional Bidang Ilmu Arsitektur dan Perkotaan:Morfologi Transformasi dalam Ruang Perkotaan yang Berkelanjutan. In Seminar Nasional Bidang Ilmu Arsitektur dan Perkotaan:Morfologi Transformasi dalam Ruang Perkotaan yang Berkelanjutan. Universitas Dipenogoro.

www.beritajakarta.id, 2017. Basuki Puji Kualitas RPTRA Sunter Jaya. Available at: http://www.beritajakarta.id/read/226 80/Basuki-Puji-Kualitas-RPTRASunter-Jaya\#.WUtKbt9LzIU [Accessed January 4, 2017].

www.fastnews.com, 2015. Ahok Resmikan Ruang Publik Terpadu Ramah Anak. Available at: http://www.fastnewsindonesia.com/a rticle/ahok-resmikan-ruang-publikterpadu-ramah-anak [Accessed September 18, 2015].

www.jakarta.bisnis.com, 2015. DKI Bangun Ruang Publik Terpadu Ramah Anak. Available at: http://jakarta.bisnis.com/read/201508 07/77/460290/dki-bangun-ruangpublik-terpadu-ramah-anak [Accessed January 18, 2016]. www.news.detik.com, 2016. Mengenal Lebh Jauh RPTRA Taman Multifungsi di Sudut Ibu Kota. Detik. Available at: http://news.detik.com/berita/2951941 /mengenal-lebih-jauh-rptra-tamanmultifungsi-di-sudut-sudut-ibu-kota [Accessed January 18, 2016]. www.tempo.com, 2015. Jakarta Tertinggi Kasus Kekerasan Seksual terhadap Anak. Tempo. Available at: http://nasional.tempo.co/read/news/2 
015/08/07/078690010/jakarta-

tertinggi-kasus-kekerasan-seksual-

terhadap-anak [Accessed January 18,

2016]. 
Spirit Publik Volume 12, Nomor 2, Oktober 2017

Halaman 43-60 P-ISSN. 1907-0489 E-ISSN 2580-3875 